\title{
Creativity in Artistic Education: Introducing Artists into Primary Schools
}

Free De Backer, Koen Lombaerts, Tom De Mette, Tine Buffel and Willem Elias

\begin{abstract}
Despite a more prominent role of arts education in the school curriculum, artistic creativity does not occur to a great extent in primary school practice. More opportunities for teachers to strengthen their know-how in the field of artistic creativity can therefore be considered important. Arts education projects focus on pupils' development of creativity by means of introducing artists with their divergent working methods into primary schools. Beside fostering pupils' creative openness and skills, arts education organisations aim to transfer artistic enthusiasm to teachers in each project. Collaboration with artists can encourage teachers' artistic creative work. New working methods, techniques or ways of experimenting are more likely to be adopted in daily teaching practice when the project duration consists of several years. However, most projects are short-lived and the means for a long-term project policy are limited. Consequently, results in the area of sustainable outcomes concerning artistic creative work with teachers are limited. To create a long-term
\end{abstract}

view, the availability of financial resources is an important condition in order to realise a mentality change towards artistic creativity in education. Finally, continuing debate with several participants about making artistic creative work sustainable remains necessary.

\section{Keywords}

arts education, artistic creativity, artists, primary schools 
Free De Backer, Koen Lombaerts, Tom De Mette, Tine Buffel and Willem Elias
Introduction

Although many people relate creativity to artistic products, it is by no means the sole prerogative of artists or of art. Creativity manifests itself in all fields of life, from science to gardening, and not everyone is equally creative in all fields (Craft $\&$ Jeffrey 2008; Prummel 2006). Many theorists have tried to define creativity. Confusion often appears in both literature and practice as a result of the absence of an unequivocal definition (Runco 2004; Steers 2009). In general, definitions are related to four different potential research areas: the creative person, process, press (i.e. the environment) and product (Batey \& Furnham 2006; Runco 2004). Despite researchers' attempts to conduct research in order to understand the concept of creativity and the fact that policymakers have increasingly recognised the importance of creativity in education during the past 20 years, the concept of creativity is often neglected in schools' curricula and practice/Craft \& Jeffrey 2008; Kaufman \& Sternberg 2007; Steers 2009). Nevertheless, from an educational point of view, the arts as a medium can stimulate several developmental areas of pupils (e.g. creative, dynamic-affective, psychomotor and social). This assumption reflects Gardner's theory of plural intelligence (1983) which challenges a onesided focus on cognitive processes in education. But in contrast to other domains such as mathematics and the natural sciences, the emphasis on arts in education has not been a priority (Robinson 2006; Walling 2001). Nowadays the development and education of children are approached from a broader perspective focusing on (meta) cognitive, affective, volitional and motorial developmental areas. As a result, the arts have acquired a more prominent place in the school curriculum than before. In this study creativity is defined as allowing pupils to give expression to impressions of experiences in a personal way (Prummel 2006). The current article reports on research examining (i) the occurrence of artistic creativity (stimulating creative processes within artistic education) in regular primary education and (ii) the impact of arts education projects which introduce artists into primary schools upon teachers' artistic creative work.
Creativity in education

Although creativity as a skill gains continuously more importance in our changing society, the occurrence and stimulation of creativity in schools are limited (Bamford 2007; Robinson 2006; Schacter etal. 2006). For example, allowing pupils to make mistakes and considering several answers provide substantial steps in the process of creativity development, whereas educational practices frequently apply the principle of the 'one correct answer' (convergent thinking). Obviously, such an approach can be considered restrictive for creativity development (de Bono 1992; Robinson 2006; Runco 2004). Research indicates that the majority of primary school teachers do not implement teaching strategies fostering pupils' creativity (Schacter et al. 2006). Moreover it was also evidenced that teachers' interpretation on how to embed creativity within the school curriculum varies: some identify creativity with particular areas of the curriculum, others consider creativity as synonymous with 'problem-solving', 'imagination' and 'lateral thinking skills' (Steers 2009). Cropley (2001, in Steers 2009) argued that teachers fostering creativity are those emphasising flexibility, accepting alternative suggestions and encouraging expression of ideas. Unfortunately, the latter group consists of a minority, as a result of a closely monitored educational system with nationally prescribed requirements such as national curricula, assessment and inspection regimes in which creativity cannot easily flourish. Creative pupils need creative teachers, but conditions of the educational system severely limit the scope for individual teachers to take creative risks (Steers 2009).

Robinson (2006) argued for a radical change within education and considered creativity at least as important as to be lettered. Although some people are more creative by nature than others in a specific domain, creative skills can be learned and therefore improved (de Bono 1992; Prummel 2006). Thus creativity should form a vital and integral part of every child's school experiences, and contribute to improved learning and increased standards across the school as a whole (Clarke 2003, in Steers 2009). A child 
will remain frequently creative and adapt itself to the changing world if its creativity is stimulated. Hence, it prospers best in a safe and stimulating climate (Prummel 2006; Steers 2009). Teachers, amongst others, can also encourage pupils to act and think creatively as well as to stimulate creative behaviour when it appears (Kaufman \& Sternberg 2007). Creativity arises when activities are presented in a permissive and gamelike fashion (Runco 2004). Curriculum coverage, task completion and the provision of psychic rewards of teaching, can be considered important contextual factors influencing teachers' commitment to implement creative and performative policies (Troman et al. 2007). In order to foster the development of pupils' creative ability, Lindström (2006) suggested four conditions for schools to pursue:

- giving pupils assignments that extend over a significant period of time and address central themes in the domain to foster their investigative work;

- teachers emphasising both process and product, and providing ample opportunity for research, experimentation and revision to foster inventiveness;

- encouraging pupils to integrate production with perception and reflection to foster the ability to use models;

- giving pupils opportunities to assess their performance and to get feedback (on explicit criteria) from peers and teachers to foster the capacity for self-assessment.

Furthermore, it is important within education to consider creativity as an attitude to life (Kaufman \& Sternberg 2007). Working with art can, for example, be an excellent and useful exercise to develop pupils' divergent thinking. Indeed, artists approach reality from different perspectives (Prummel 2006). Hence, creative challenges, both in terms of applied teaching strategies and presented opportunities for pupils to develop creative responses, characterise the significance of art in establishing a vital and effective learning environment (Parker 2005).
Artistic creativity in the Flemish

educational context

In 1998 the Flemish government of Belgium (Europe) introduced attainment targets or minimum goals considered necessary and achievable for students in regular formal education. At primary education level, a separate set of targets was developed for the field of artistic education. From then on, the arts acquired a prominent place in the primary education curriculum in the Flemish region of the country. The subject domain of artistic education focuses on the development of children's creative and expressive opportunities in order for them to learn, think and act independently. In artistic education, teachers can stimulate individual's own contributions rather than using an example which everyone has to imitate: in other words, allowing pupils to give expression to their impressions of experiences in a personal way. The latter is an essential part of creativity. Thus, artistic education can be considered a fertile area for the development of creativity, and is now a general learning goal within the current primary education curriculum (Prummel 2006: Van Ransbeeck 1996).

It is important continuously to stimulate creativity during artistic education. After all, being artistically active does not automatically imply pupils working creatively. For example, singing along with a song can be considered an artistic act, but is not necessarily creative. Imitation and repetition are important aspects of learning, but can hardly be considered creative (Prummel 2006; Van Ransbeeck 1996). Research shows that teaching in a creative way leads more easily to creative behaviour in pupils (Jeffrey \& Craft 2004). However, such an approach rarely occurs in the domains of artistic education. These domains are often characterised by little creativity and are therefore unsuited to pupils' current needs (Elias \& Duquenne 2002).

Teachers tend to approach artistic attainment targets in a traditional way, as mentioned above (Elias \& Duquenne 2002). An important reason for this is that teachers are not equipped to meet the needs of pupils in terms of creativity. Teachers do not appear to know how to initiMette, Tine Buffel and Willem Elias 
Free De Backer, Koen Lombaerts, Tom De Mette, Tine Buffel and Willem Elias ate, conduct or evaluate creativity (Schacter et al. 2006; Torrance \& Safter 1986). Schools currently have a need for support within the domain of arts education (De Grauwe 2005; Steers 2009). School principals and policymakers argue for more opportunities for teachers to strengthen their know-how, to stimulate artistic creativity of pupils, in order to achieve the formulated attainment targets. As a result, schools increasingly appeal to the expertise of specialised arts education organisations (De Grauwe 2005; Van Petegem et al. 2007). An interesting option is to set up a cooperation project with an arts education organisation which, by introducing artists into schools, immerses a class or even the whole school in the world of arts. These projects emphasise creative development by maximising creativity in pupils' daily reality by confronting them with arts. Besides training in technical artistic skills, artists also offer surprising perspectives on the world. In their contact with pupils they emphasise alternatives to an otherwise one-sided cognitive stimulation, and reduce pupils' psychological distance to the world of art. Artists are also able to improve or expand current teaching practices and create a school climate fostering creativity. In other words, they can function as positive role models for both pupils and teachers. Such projects can motivate and inspire the artistic creativeness of teachers in their daily teaching practice. Overall, when working together with artists, teachers become acquainted with other approaches that exceed the conventional interpretation of artistic education (Anckaert 2007; Elias \& Duquenne 2002; Robinson 1999).

\section{Purpose and research questions}

The main focus of this study is the occurrence of artistic creativity in primary education. The present study focuses on primary school practices for two reasons. First, the level of primary education and particularly the curricular structure, provides opportunities and a lot of flexibility for teachers to enhance artistic creativity in artistic education as well as creativity in general over all curricular domains. Second, the level of primary education can be considered important in the development of (artistic) creativity (Kracman 1996). Artistic creativity refers to creative processes within the artistic domains of education. Stimulating creativity within artistic education allows pupils to give expression to impressions of experiences in a personal way. The first objective of the study was to explore the extent to which both teachers and artists from arts education organisations stimulate artistic creativity in primary school practice. The second objective was to examine how arts education organisations introducing artists into primary schools strive for sustainable outcomes with teachers in the field of artistic creativity.

The following research questions were addressed:

1. To what extent do primary school teachers and artists stimulate pupils' creativity processes in artistic education (projects)?

2. How and to what extent do artists strive for sustainable outcomes regarding their artistic creative work with teachers?

\section{Method}

The present study was conducted in two research stages. The first stage involved the analysis of the activities of arts education projects in primary schools. Interviews with both project coordinators and artists were conducted to investigate the policy and the practice of the arts education projects. In the second stage, the perceptions of primary school teachers were investigated regarding their initiatives in artistic creativity, and the results of their cooperation with artists and arts education organisations. In this section the main characteristics of sample and instrument, as well as data analysis, are described for both research stages separately.

Research stage 1:

Analysis of arts education project activities

\section{Sample}

The starting point for sample selection was the Federation of Organisations for Arts Education in Belgium (Europe). Within the federation 
member organisations, arts education projects were selected on the basis of two criteria: (1) all fields of artistic education (visual arts, drama, music, media and dance) belong to the scope of the organisation; and (2) the organisation introduces professional artists into primary schools. Furthermore, organisations that were not subsidised during the past school year, or received no specific subsidies for such projects, were also left out of consideration. This procedure resulted in five arts education organisations being incorporated in this research stage.

\section{Instrument}

In this research stage the project coordinator and two artists from each organisation were questioned in expert interviews. Besides a different educational background all artists were professionally active in arts education and had pedagogical and artistic knowledge in their domain. Different interview schemes were used when questioning the coordinators and the artists. The coordinator's interview scheme (Appendix 1) was composed of a series of questions assessing three main subject areas: (1) vision on artistic creativity and corresponding objectives formulated by the organisation; (2) the nature and scope of cooperation projects within primary schools; and (3) the achievement of sustainable project outcomes. The interview scheme for the artist (Appendix 2) comprised two main subject areas: (1) personal view on artistic creativity; and (2) the way sustainable project outcomes were aimed for. In three organisations the coordinator also worked as an artist. In this case, the two interview schemes were interwoven. The respondents $(n=12)$ were questioned on the basis of semi-structured interviews allowing for the posing of additional questions if necessary, or anticipating answers that were relevant within the research objectives. Both the mission and vision of each organisation were analysed in advance and used to complete the interview where necessary. Occasionally, and on the request of the organisation, an updated policy document was also used to complete the interview.

\section{Data analysis}

To analyse the data of this research stage five text files were set up, each one consisting of al interviews of one arts education organisation. Interviews were fully transcribed and read through repeatedly. The interview manuscripts were subjected to a content analysis using the inductive and conceptual mapping procedure (Charmaz 2006). With the interview framework as starting point, re-occurring themes, common patterns and key points were identified. In order to guarantee categorisation reliability, four researchers independently examined these themes for consistent patterns. Minor adjustments in grouping or splitting up data categories were made. Afterwards, the 'labelling method' (Burns 2000) was applied on each interview manuscript, selecting information of relevance to the research questions. Then the selected text was split up into fragments and labels were assigned. Based on these fragments and labels, a synthetic picture of the organisation was structured. This process was repeated for each case study. Afterwards, a horizontal analysis was conducted, allowing us to interpret the results over all organisations, after which some general tendencies became clear.

\section{Research stage 2:}

Exploratory analysis of teachers' initiatives

\section{Sample}

The sample was composed of teachers from schools in and around the Brussels Capita Region (Belgium) and was stratified according to governance (private/public) and region (urban/ suburban). In advance, a target figure of 50 participating schools was assumed. To reach this quota 60 schools were contacted (response percentage of 85 per cent). The number of questionnaires per school that was filled in by teachers depended on the readiness of each individual teacher to participate. The questionnaire was filled in by 248 respondents. Some 81 per cent of them were women, which matches the real gender segmentation within primary education. Teachers had an average age of 38 , an aver- 
Free De Backer, Koen Lombaerts, Tom De Mette, Tine Buffel and Willem Elias

Table 1: Factor loadings for items within scale for artistic creativity $(n=248)$

\begin{tabular}{|lr|}
\hline & Factor \\
\hline Experiment with dance movements & 0.86 \\
\hline Introduce movements oneself & 0.86 \\
\hline Act out a situation (walking through the countryside, making large purchases & 0.60 \\
in a store, being a pop star, dancing to portray the wind or rainfall, expressing & \\
\hline by movements a sense of danger or happiness) & 0.55 \\
\hline Improvise a little dance oneself in preparation for, or on the occasion of, & 0.54 \\
\hline a class party, nature classes, leaving primary school & 0.52 \\
\hline Free oneself to express movements, images, texts, evoked atmosphere, & 0.40 \\
\hline emotion with musical aspects & 0.36 \\
\hline Imagine and imitate the ball in Wonder Palace & 0.33 \\
\hline Making a song oneself & \\
\hline Improvise by means of instruments & fishes move, big birds fly, a plane takes off, a boat sails... \\
\hline
\end{tabular}

age seniority of 15 years and the mean number of pupils per class amounted to almost 21 .

\section{Instrument}

In this research stage, a questionnaire was developed and presented to primary school teachers.

The first part consisted of questions assessing the extent to which teachers stimulate creativity within artistic education. A scale was developed to measure teachers' initiatives to stimulate artistic creativity. Several practical situations were formulated, and teachers were asked to score these in accordance to their own approach within artistic education. The basis for the development of the scale items were derivatives/examples of various attainment targets for artistic education (Ministry of Flemish Community 1998). Items consisted of examples both illustrating the stimulation of merely artistic and artistic creative initiatives within artistic education. The latter distinction was derived from the literature study indicating that being artistically active does not automatically imply pupils working creatively (Prummel 2006). Examples that focus on imitation, repetition and routine were not considered to be creative. For example, when a teacher scored high on an item such as 'teaching a song', we considered this as atten- tion for artistic education but not for creativity within artistic education. When a teacher scored high for the item 'making a song oneself', we considered this as attention to stimulating creativity within an artistic field. Items were formulated on a five-point Likert scale ranging from '(nearly) never' to '(nearly) always'. The psychometric qualities of the selected item list are presented in Table 1.

From the 16 formulated items measuring teacher initiatives with regard to artistic education, seven items were not taken into consideration due to the absence of any reference to creativity in their content. Maximum likelihood factor analysis was implemented to check whether the formulated items would produce a workable scale measuring artistic creativity. This ended in a 1-factor solution. This factor was labelled 'artistic creativity' and measures the extent to which teachers stimulate creativity within artistic education (eigenvalue $=3.75$; explained variance $=41.6 \%$ ). An overview of the factor loadings is presented in Table 1. Cronbach alpha for the 'Artistic Creativity' scale was 0.82 .

The second part of the questionnaire focused on teachers' experiences with projects introducing an artist into the school. With regard to the explorative character of this stage, there was no guarantee that a teacher already worked 
together with an artist. This criterion could not be assumed in advance during sample selection. However, the current approach has the important advantage that we could assess the degree to which such projects occur. This part of the questionnaire included both closed and open questions.

\section{Data analysis}

The quantitative data were analysed through descriptive and multivariate statistical techniques. Qualitative data resulting from the questionnaire (open-ended questions) were quantified for further analysis. Based on the theoretical framework, important components of artistic creativity were labelled, quantified and reported as percentages (e.g. the questionnaire contained an open-ended question 'How were you as a teacher involved during the project when the artist worked in your classroom?'; qualitative teacher data were categorised as (0) no involvement, (1) maintaining class discipline, (2) assisting the artist in guiding pupils, (3) joining actively in the artistic creative process).

\section{Findings}

\section{Research stage 1: Analysis of arts education project activities}

This study focused on both short-lived and longterm projects that are implemented within an educational context. Both project coordinators and artists were well informed about, and familiar with, the attainment targets. Some projects were completely set up with the artistic attainment targets as the starting point. However, most took the attainment targets into account while setting up a project. The way organisations stimulate artistic creativity differed strongly. Most organisation members reported the importance for artists of being able to respond to spontaneous impulses. Each organisation focused on process as well as product, but the extent into which both were approached, differed. The methods used (both pedagogical and specific art methodology) differed, depending on time, target group, specific demands of the school and the approach of the individual artist. These methods could be applied to individuals, pairs of pupils and/or in groups. Respondents also attached great importance to reducing insecurity feelings for children. Furthermore, in almost every interview it was stated that pupils were to experiment and nothing was to be imposed upon them during art classes. All organisation members argued that different art disciplines could be integrated within an artistic project.

Respondents pointed out a noticeable increase in teachers' artistic creative work in primary schools over the past few years. Nevertheless, all respondents reported a strong variation on school and individual teacher level. Respondents reported several reasons to explain such differences: the amount of work of the teacher, the readiness of the management, acquaintance with the branch of art, infrastructure, the emphasis on product/process and school climate. Furthermore, both coordinators and artists reported several reasons why pupils' creativity can be obstructed: pupils are not allowed to make mistakes at school and teachers too often have an elaborate scheme. Besides giving more attention to the domain of artistic creativity within teacher training programmes, respondents emphasised the need for continuous attention within the school.

Not all the organisation members had a clear idea about how to achieve sustainable project outcomes such as changes in teachers' mentality concerning artistic creativity. Yet almost al respondents indicated that a perceptible increase in the way that teachers foster artistic creativity can only be realised when project duration consists of a minimum of five years (on average).

Although arts education organisations put pupils at the centre of their projects, they also reported focusing on teacher involvement during project execution. Artists reported that the kind of involvement depended on the openness and readiness of the individual teacher Nevertheless, all projects promoted active teacher involvement (e.g. assisting the artist in guiding pupils' artistic creative work, participating with the pupils, continuing the project in the absence of the artist) as it is stimulating for Lombaerts, Tom De Mette, Tine Buffel and Willem Elias 
Free De Backer, Koen Lombaerts, Tom De Mette, Tine Buffel and Willem Elias

Table 2: Average scores for items that search for teachers' initiatives in the sphere of artistic education and general scale score for items that measure artistic creativity

\begin{tabular}{|c|c|c|}
\hline & Average & S.D. \\
\hline Singing along or clapping during a known melody & 2.68 & 0.85 \\
\hline Teaching a song & 2.67 & 0.92 \\
\hline Learning to sing a varied repertoire of songs properly & 2.22 & 1.08 \\
\hline $\begin{array}{l}\text { Act out a situation (walking through the countryside, making large } \\
\text { purchases in a store, being a pop star, dancing to portray the wind or } \\
\text { rainfall, expressing by movements a sense of danger or happiness)* }\end{array}$ & 2.12 & 0.97 \\
\hline Introduce movements oneself* & 2.05 & 1.05 \\
\hline $\begin{array}{l}\text { Free oneself to express movements, images, texts, evoked atmosphere, } \\
\text { emotion with musical aspects* }\end{array}$ & 1.97 & 1.05 \\
\hline $\begin{array}{l}\text { Improvise a little dance oneself in preparation for, or on the occasion of, } \\
\text { a class party, nature classes, leaving primary school* }\end{array}$ & 1.87 & 1.05 \\
\hline Act out how fishes move, big birds fly, a plane takes off, a boat sails...* & 1.76 & 1.05 \\
\hline Experiment with dance movements* & 1.70 & 1.08 \\
\hline Teaching existing dance steps & 1.64 & 1.04 \\
\hline $\begin{array}{l}\text { Implementing several little dances for different occasions } \\
\text { (a birthday party, the seasons, a carnival, ...) }\end{array}$ & 1.62 & 1.01 \\
\hline Imitating sounds of animals, a thunderstorm... & 1.56 & 0.85 \\
\hline Improvise by means of instruments* & 1.45 & 0.80 \\
\hline Trying out self-made instruments & 1.02 & 0.78 \\
\hline Making a song oneself* & 0.85 & 0.66 \\
\hline Imagine and imitate the ball in Wonder Palace* & 0.79 & 0.88 \\
\hline *Artistic creativity total scale score & 40.51 & 15.6 \\
\hline
\end{tabular}

pupils and teachers themselves learn a lot from these project experiences. On the other hand, other forms of participation were considered unpleasant and even impeding: for example, stressing classroom order or fulfilling completely different tasks.

Respondents reported several initiatives that are used to make their artistic creative work sustainable, such as having conversations with teachers during and after sessions with further explanation about techniques, passing on specific artistic exercises, allowing teachers to observe and participate during sessions, providing teachers with feedback about their lessons and practice, involving teachers' ideas during workshops.

\section{Research stage 2: Exploratory analysis of teachers' initiatives}

Table 2 presents an overview of teachers' initiatives in the domain of artistic education. Results show that the items on which teachers scored the highest were those measuring artistic rather than artistic creative activity. Teachers' average total score on the 'Artistic creativity' scale was 40.51 (see Table 2). This score can be interpreted as teachers' stimulation of artistic creativity being limited. Indeed, considering the answer 
categories of the questionnaire this score fitted in with the upper limit of 'very little' and the lower limit of 'sometimes' (ranges of 20-40 and 40-60, respectively).

Teachers were also explicitly asked how creativity development was stimulated within artistic education. Some 43 per cent of the teachers were convinced that artistic education allowed pupils' own contributions (e.g. pupils may invent something themselves, may act out their fantasy or may improvise). The extent to which teachers actually stimulate pupils' contribution strongly varies among individual teachers. Furthermore, 20 per cent of the teachers indicated that in their classroom practice a specific technique is explained. Afterwards pupils may have the opportunity to act out their own fantasies in practising the technique.

Some 33 per cent of the respondents reported already having worked with an artist in their classroom practice. However, the proportion of artists from an arts education organisation was only a fraction of this percentage, indicating that arts education organisations are only marginally embedded into primary education practice. The cooperation with artists often tends to be established on an accidental basis: artists visiting classes were often not associated with an external project. For example, projects in cooperation with arts education organisations received low scores from teachers as a source of inspiration with regard to artistic education. In contrast, educational websites and colleagues were considered extensively as sources of information and inspiration.

Reported initiatives with artists (both individuals and associates with arts education organisations) were mainly of short duration. Although every teacher was asked to report about projects with artists during their entire school career, their experience of projects tends to be a once-only initiative for 73 per cent of the teachers. In addition, if a teacher indicated that they were engaged in a project with an artist, it was often the case for a number of teachers in the same school (Cramer's V for nominal variables $=0.62 ; \mathrm{p}<0.001$ )

Most artists belonged to the field of visual arts, and to a lesser degree music or were authors. From the one out of three teachers that already had an artist in the classroom, 43 per cent reported their task to be mainly assisting the artist in guiding pupils. Active joint approaches occurred, but to a much lesser degree (22 per cent).

The methods artists use can either be categorised as class workshops, individual guiding sessions or smaller team work. Combinations of all three also occurred. Teachers reported that artists often provided an initiation first (like, for example, a demonstration of their work or explaining a technique), followed by a session allowing pupils to work by themselves or in a group. Almost half of the teacher sample (48 per cent) reported that they had gained ideas during this cooperation with regard to the techniques that were used. Furthermore, 41 per cent of teachers reported that they had learned a lot from the approach of the artist(s), especially the way of introducing a theme, coming to a result in classroom practice and the way the children were coached

\section{Conclusion and discussion}

The first objective of the study was to examine the extent to which creativity is stimulated during artistic education practice in primary schools. Members of arts education organisations reported a noticeable increase of teachers artistic creative work in primary schools during the past few years, with a strong variation between schools and individual teachers. Survey results indicated that teachers stimulate artistic creativity but on an irregular basis Indeed, teachers were found to stimulate artistic rather than artistic creative outcomes for pupils. Similar findings were reported when members of the arts education organisations were consulted. This is in line with other research (Atkinson 2006). In contrast, the present study revealed that arts education projects focus on pupils' creativity development during projects by means of divergent working methods.

The second objective of the study was to examine how arts education organisations strived for sustainable outcomes with teachers
Free De Backer, Koen Lombaerts, Tom De Mette, Tine Buffel and Willem Elias 
Free De Backer, Koen Lombaerts, Tom De Mette, Tine Buffel and Willem Elias through cooperation with artists. Besides their work with pupils, artists also encouraged teachers to adopt an artistic creative approach Although all members of the organisations strongly preferred that teachers were actively involved during projects, this seemed not to be a widespread practice. Nevertheless, the organisation members reported that arts education projects provide effective learning opportunities for the teacher when the teacher is involved. Moreover, the enthusiasm of the teacher was considered important in stimulating pupils. This study indicated that a significant proportion of the teachers working with an artist in their classroom assisted the artist during the process but did not actively participate with the pupils. However specific methods to stimulate pupils' artistic creativity were shared with teachers. But in this matter, project members reported limited results in the area of sustainable outcomes concerning artistic creative work with teachers. The members of almost every organisation pointed out that a perceptible increase in teachers fostering artistic creativity is only possible if the artists visit the school repeatedly. New working methods, techniques or ways of experimenting are only adopted in daily teaching practice when artists visit the school repeatedly over a longer period. Teachers confirmed adoption of these techniques in their classroom practice. Unfortunately, members and teachers also reported most projects to be short-lived and the resources for a long-term project policy being limited.

\section{Methodological limitations}

Some shortcomings should be mentioned when interpreting the research results of the present study. First, the varying context of each case study should be taken into consideration during the first research stage. Detrimental to this study is the impossibility to assess if the answers which were given effectively apply to the educational context, because the organisations also play a very active part in other fields (such as arts and cultural centres and youth work).

A critical remark in the second research stage is that the concept of artist was open to many interpretations, and could therefore produce some doubt with teachers when interpreting the term. Moreover, it was difficult to draw conclusions from answers to the question as to whether methods were still applied, because teachers were not explicitly asked to indicate this to be an objective of the artist in the class. The question concerning the extent to which methods are still used was also only indirectly included in the survey. The same remark applies to the criterion as to whether a teacher had already cooperated with an artist (in particular from an arts education organisation). This was not used as a condition during sample selection.

\section{Practical implications and recommendations}

Continuous professional development of teachers is of crucial importance for qualitative arts education in schools. The present study showed that teachers considered their colleagues as important partners in artistic education. In this matter, the development of a forum where teachers and (arts) education experts could meet each other and exchange information (e.g. about current projects), could be an important source of inspiration. Furthermore, an arts education supervisor at school level could respond to the schools' needs with the knowledge and selection of specific partners. On a macro level an official body could operate as such a supervisor of arts education and could manage the suggested forum.

Although creativity should form a vital and integral part of the schools' curricula and practice, literature clearly indicated that creativity is usually neglected and teachers are not equipped to meet the needs of pupils in terms of creativity (Craft \& Jeffrey 2008; Schacter et al. 2006; Steers 2009; Torrance \& Safter 1986). A blend of motivated teachers, together with artists (from arts education organisations) and experts in the field, could examine the feasibility and practical value of the artistic attainment targets and could be involved in the construction of the general and artistic school curriculum. After all, the members of such organisations have a clear view on creativity development and could challenge policymakers to question and adapt current curriculum content and peda- 
gogy where necessary.

The current study results suggest that arts education organisations can stimulate artistic creativity from a dual perspective: on the one hand fostering pupils' creative openness and skills, and on the other hand transferring artistic creative enthusiasm to teachers. Members of arts education organisations reported that although teachers adopt some ideas and methods, sustainable changes can only occur if artists visit the school for a relatively long time. For this reason short-term projects should not be reduced or abolished. After all, every initiative must be considered as an important contribution if the schools' views on creativity are to be permanently supported and intensified. But such investments have financial repercussions and are therefore a clear policy issue. At present, the budget is rather limited, so that several organisations restrict their field of activity to just a few schools. Besides more investment, policymakers should stimulate the dissemination of the applied methods because of the added value for education in general and organisations' own practice. A support institution for arts education could fulfil an important role in advising both the government and arts education authorities about a sustainable arts education policy. Finally, a continuing debate about sustainability of artistic creative work remains necessary between all partners on different levels (micro, meso and macro level).

\section{Follow-up study}

The present study should be considered only as an initial study into the area of artistic creativity by analysing the influence of arts education projects introducing artists into primary schools. This study intends to encourage other researchers to investigate relevant themes in this area. In our opinion, future research projects are especially needed to reveal how the activities of arts education organisations can be adjusted to realise sustainable results. First, it would be advisable to select only teachers who had actually worked with artists in primary schools to obtain thorough information. A broader questioning of experts in schools providing good practices as well as cultural centres, museums and youth associations, where arts education organisations are actively involved, would also inevitably provide additional insight on this research topic.

Appendix 1.

Project coordinator interview scheme

* Introduction and presentation of professional job responsibilities.

* Project background: (a) Design: whole school year project design (period and duration), short-period project design (thematic, project week, ...), single project in number of schools? (b) Scale: number of artists, number of schools, coordination,...

\section{Vision on artistic creativity and corresponding objectives formulated by the organisation:}

a. What is meant by artistic creativity? To what extent does the organisation strive for artistic creativity in the conducted projects?

b. Project aim and approach versus the artist's freedom of project implementation (to what extent is an artist free regarding how to work within schools; how are the project aim and the proposed approach/method passed on to the artists?)

\section{The nature and scope of cooperation projects within primary schools:}

a. How do schools participate in a project? What are the most important motives of schools to participate/subscribe?

b. To what extent can schools or teachers contribute to the aim of a project?

c. Which methods are used to stimulate pupils' artistic creativity? (learning principles, education methods, didactical approach; focus on artfrom an active, passive, reflective or receptive perspective)

d. Are projects set up with the attainment targets as a starting point or as a guiding principle? In what way? If so, is this on demand of the schools or from the organisation?

e. Opinion concerning the current educational policy on art(istic) education (attainment
Free De Backer, Koen Lombaerts, Tom De Mette, Tine Buffel and Willem Elias 
Free De Backer, Koen Lombaerts, Tom De Mette, Tine Buffel and Willem Elias targets)? Realisable? Recommendations? Enough emphasis on creativity within artistic education?

\section{The achievement of sustainable outcomes:}

a. Aim of the project at sustainable outcomes with pupils inside or outside the school (e.g. strong focus on pupils; that they also work further outside the classroom)? How do the artists pursue such sustainable outcomes?

b. Involvement of the teachers in the project to stimulate sustainable outcomes?

c. How are teachers stimulated to adopt the project method(s) and approach? What are your personal experiences in this matter?

Appendix 2.

Artist interview scheme

* Introduction and presentation of professional job responsibilities.

* Topics:

1. Personal view on artistic creativity:

a. Vision about artistic creativity within the project?

b. Use of methods to stimulate pupils' artistic creativity?

c. Expectations concerning teachers' role during the project? Is there enough stimulation to work creatively in schools? Factors interfering with creativity stimulation?

d. Consideration of pupils' interests within the artistic domains and what they already practise outside the school? Aim within the project towards possibilities to make the pupil's whole artistic creative process selfregulated? Describe process?

e. Opinion concerning the current educational policy on art(istic) education (attainment targets)?

\section{Sustainable project outcomes:}

a. Aim of the project at sustainable outcomes with pupils inside or outside the school? How?

b. Involvement of the teachers in the project to stimulate sustainable outcomes? c. How are teachers stimulated to adopt the project method(s) and approach? How is this assessed? Does the teachers' view regarding artistic creativity change during and after the project?

Free De Backer works at the Department of Educational Sciences of the Vrije Universiteit Brussel. She is currently preparing her PhD within the domain of arts and museum education. She presented (with Lombaerts, De Mette and Elias, 2011) Flirting with museum educational tools: combining the visitor and museum educator perspective at the ICOM CECA Annual Conference 2011, Zagreb, Croatia. She has published (with Elias, Lombaerts and De Mette, 2008) Artistic creativity in primary school: the influence of art education projects, European InfoNet Adult Education, No. 6 (online) and (with Lombaerts, Engels, van Braak and Athanasou, 2009), Development of the self-regulated learning teacher belief scale, European Journal of Psychology of Education, Vol. 24, No. 1, pp. 79-96. Contact address: Department of Educational Sciences, Vrije Universiteit Brussel, PleinIaan 2, 1050 Brussels, Belgium. Email: Free. De.Backer@vub.ac.be

Koen Lombaerts works at the Department of Educational Sciences of the Vrije Universiteit Brussel. His teaching and research focus on selfregulated learning environments and lifelong learning. He has published articles on self-regulated learning in European Journal of Psychological Education (with De Backer, Engels, van Braak and Athanasou, 2009), Journal of Educational Research (with Engels and van Braak, 2009) and Perspectives in Education (with Engels and Athanasou, 2007). Contact address: Department of Educational Sciences, Vrije Universiteit Brussel, Pleinlaan 2, 1050 Brussels, Belgium. Email: Koen. Lombaerts@vub.ac.be

Tom De Mette is a philosopher within the Department of Educational Sciences of the Vrije Universiteit Brussel. His research focuses on cultural and art policy, and cultural, media and 
art philosophy. He is currently working on a doctoral dissertation on new media art and arts education. He has published (with Van Moer and Elias) From obstacle to growth: Dewey's legacy of experience-based art education, International Journal of Art \& Design Education, Vol. 27, No. 1, pp. 43-52. Contact address: Department of Educational Sciences, Vrije Universiteit Brussel, Pleinlaan 2, 1050 Brussels, Belgium. Email: tdemette@vub.ac.be

Tine Buffel works on a scholarship from the Fund for Scientific Research Flanders at the Department of Educational Sciences of the Vrije Universiteit Brussel. Her research focuses on community development, and the social and cultural aspects of ageing. She presented (with Verté, Dury and De Witte, 2009) Conceptualizing the neighbourhood as a dynamic social space: recognizing older people as actors in placemaking, Paper at the Ninth Conference of the European Sociological Association, Lisbon, Portugal, and is publishing (with Verté, De Donde, De Witte, Dury, Vanwing and Bolsenbroek) Theorising the relationship between older people and their immediate social living environment, International Journal of Lifelong Education (in press). Contact address: Department of Educational Sciences, Vrije Universiteit Brussel, Pleinlaan 2, 1050 Brussels, Belgium. Email:Tine.Buffel@vub.ac.be

Willem Elias is professor at the Department of Educational Sciences of the Vrije Universiteit Brussel. His teaching and research focus on arts education, cultural philosophy and policy, and contemporary art theory. He has published Aspects of Belgian art after 1945: Part / (Snoeck Publishers, 2005) and (with Van Moer and De Mette, 2008) From obstacle to growth: Dewey's legacy of experience-based art education, International Journal of Art \& Design Education, Vol. 27, No. 1, pp. 43-52. Contact address: Department of Educational Sciences, Vrije Universiteit Brussel, Pleinlaan 2, 1050 Brussels, Belgium. Email: w.elias@edpnet.be

\section{References}

Anckaert, L. (2007) Kunsteducatieve

vormingsprocessen [Arts Educational Training

Processes]. Antwerp-Apeldoorn: Garant

Atkinson, D. (2006) School art education: mourning the past and opening a future, International Journal of Art \& Design Education, Vol. 25, No. 1, pp. 16-27

Bamford, A. (2007) Quality and Consistency: Arts and Cultural Education in Flanders.

Brussels: Agency for Educational

Communication

Battey, M. \& Furnham, A. (2006) Creativity, intelligence, and personality: a critical review of the scattered literature, Genetic, Social, and General Psychology Monographs, Vol. 132, No. 4, pp. 355-429

Burns, B. R. (2000) Introduction to Research Methods. London: Sage

Charmaz, K. (2006) Constructing Grounded Theory: A Practical Guide through Qualitative Analysis. London: Sage

Craft, A. \& Jeffrey, B. (2008) Creativity and performativity in teaching and learning: tensions, dilemmas, constraints, accommodations and synthesis, British Educational Research Journal, Vol. 34, No. 5, pp. 577-84

de Bono, E. (1992) Teach Your Child How to Think. London: Viking

De Grauwe, J. (2005) Het beleid van de kunsteducatie in Vlaanderen: een algemene schets, casestudy en kritische analyse [The Policy of Arts Education in Flanders: A General Sketch, Case Study and Critical Analysis].

Antwerp: De Veerman

Elias, W. \& Duquenne, E. (2002) Cultuur en onderwijs, een dialoog uit het absurd theater? [Culture and education, a dialogue from the theatre of the absurd?], Persoon en Gemeenschap, Vol. 54, No. 5, pp. 301-25
65

Free De Backer, Koen Lombaerts, Tom De Mette, Tine Buffel and Willem Elias 
Free De Backer, Koen Lombaerts, Tom De Mette, Tine Buffel and Willem Elias
Gardner, H. (1983) Frames of Mind: The Theory of Multiple Intelligences. New York: Basic Books

Jeffrey, B. \& Craft, A. (2004) Teaching creatively and teaching for creativity: distinctions and relationships, Educational Studies, Vol. 30, No. 1, pp. 77-87

Kaufman, J. C. \& Sternberg, R. J. (2007) Resource review: creativity, Change, Vol. 39, No. 4, pp. 55-8

Kracman, K. (1996) The effect of school-based arts instruction on attendance at museums and the performing arts, Poetics, Vol. 24, No. 2-4, pp. 203-18

Lindström, L. (2006) Creativity: What is it? Can you assess it? Can it be taught? International Journal of Art \& Design Education, Vol. 25, No. 1, pp. 53-66

Ministry of the Flemish Community, Department of Education and Training, Information and Documentation Division (1998) Development Goals and Attainment Targets. Information File for the Educational Practice. Regular (Pre) Primary Education. Brussels: Author

Parker, J. (2005) A consideration of the relationship between creativity and approaches to learning in art and design, International Journal of Art \& Design Education, Vol. 24, No. 2, pp. 186-98

Prummel, J. (2006) Het deurenpaleis, over creativiteit en onderwijs [The Palace of Doors, about Creativity and Education]. Brussels: CANON

Robinson, K. (1999) Culture, Creativity and the Young: Developing Public Policy. Strasbourg: Council of Europe

Robinson, K. (2006) Do schools kill creativity? (online). Available at: www.ted.com/index.php/ talks/view/id/66 (accessed 1 December 2007)

Runco, M. A. (2004) Creativity, Annual Review of Psychology, Vol. 55, No. 1, pp. 657-87
Schacter, J., Thum, Y. M. \& Zifkin, D. (2006) How much does creative teaching enhance elementary school students' achievement? Journal of Creative Behavior, Vol. 40, No. 1, pp. 47-72

Steers, J. (2009) Creativity: delusions, realities, opportunities and challenges, International Journal of Art \& Design Education, Vol. 28, No. 2, pp. 126-38

Torrance, E. P. \& Safter, H. T. (1986) Are children becoming more creative? Journal of Creative Behavior, Vol. 20, No. 1, pp. 1-13

Troman, G., Jeffrey, B. \& Raggl, A. (2007) Creativity and performativity policies in primary school cultures, Journal of Education Policy, Vol. 22, No. 5, pp. 549-72

Van Petegem, P., Engels, N. \& Rymenans, R. (2007) De perceptie van eindtermen en ontwikkelingsdoelen in het basisonderwijs bij leerkrachten en directies. OBPWO-project 04.03 [The Perception of Attainment Targets and Development Goals in (Pre-)Primary Education among Teachers and the Management. OBPWO-project O4.03]. Brussels: Ministry of the Flemish Community, Department of Education

Van Ransbeeck, A. (1996) Muzische vorming. Bijlage bij de Gids voor het Basisonderwijs [Artistic Education. Appendix with the Guide for (Pre-) Primary Education]. Diegem: Kluwer Editorial

Walling, D. R. (2001) Rethinking visual arts education: a convergence of influences, Phi Delta Kappan, Vol. 82, No. 8, pp. 626-31 